\title{
Sports management in protected mountain areas. Sustainable development through collaborative network governance: a case study
}

\author{
Eduard Inglés-Yuba, Núria Puig \& Víctor Labrador
}

Keywords: governance, collaborative network, sustainable development, sports, coastal protected area

\section{Abstract}

This study aims to determine the effect of a collaborative network governance structure in the management of sports practice in protected mountain areas on the degree of sustainability of its territorial development. This paper presents the results of an analysis of the existing governance in the decision-making processes of four conflict situations generated by sports practice in two protected mountain areas, and the effects on the development dimensions of each case. The method used to collect the data were in-depth qualitative interviews with key stakeholders. To allow a comparison between cases, qualitative information was quantified by the definition of indices of indicators.

Results show that a correlation exists between the index of collaborative network and that of sustainability; that means that the greater the degree of networking and collaboration between stakeholders, the higher the degree of sustainability of the development generated by the strategy of solutions adopted in each of the analysed cases.

\section{Profile}

Protected area

Montseny Natural Park

and Garraf Park

Mountain range

Cordillera Prelitoral

and Litoral

Country

\section{Spain}

\section{Introduction}

The impact of sports practice on the natural environment increasingly concerns scholars from a variety of disciplines (Dingle 2009). There is an urgent need to reduce its negative effects and contribute to more sustainable development (Mallen et al. 2010).

In recent years there has been an exponential in crease in the sports use of natural areas, resulting in their massive use and exploitation (Fyall \& Jago 2009). This fact led to an intensification of the impact of sports on the natural, social and economic conditions of the territory where they are practiced (De Andrés et al. 1995; Lagardera \& Martínez 1998). The lack of a global response in terms of policies or regulation means that the responsibility falls on the decisions taken by the managers and people in charge of controlling the natural areas. Thus a management model needs to be created that offers solutions for sports managers in natural areas.

This work aims to contribute to the analysis of the effects of the mode of governance in the management of sports practice on the degree of sustainability of the development achieved in natural areas. We empirically assess the effects generated by the relationships established and the collaboration processes used by the stakeholders involved on the management of sports practice and on the different dimensions of the development of natural areas: ecological, economic, social (WCED 1987) and institutional (Sepúlveda 2008; Inglés 2013). The main objective of the study is to determine whether a collaborative network governance structure in the management of sports practice in natural areas generates better effects on the degree of sustainability of development of the area.

This paper analyses the managing processes of four conflict situations generated by sports practice in two protected mountain areas and the effects on the development dimensions of each case. The information was gathered through in-depth qualitative interviews with key stakeholders and indices of indicators were defined for the quantification of qualitative data and to allow comparison between cases.

\section{Theoretical framework}

Governance: collaborative network

To define the notion of governance, here are two of its broadly used meanings (Mayntz 1998):

1. Governance as an alternative to hierarchical control. Governance refers to a new style of government, based on a greater degree of cooperation between different actors (Rhodes 1997);

2. Governance as any form of social coordination. Governance is considered a primary form of constructing social order; governance, therefore, also indicates any form of social coordination at any level, especially networks (Powell 1990).

Several studies have focused on the modes of governance of sports practice or tourism and recreational activities in protected natural areas (Durán 2009; Sharma \& Kearins 2011). In the present study we focus on the concepts of network and collaboration, coining the notion of collaborative network governance. 
A network is conceived as a current structure (as opposed to a metaphorical or analytic tool) that includes multiple nodes - agencies and organisations -, and multiple links, usually involved in collaborative activities (McGuire 2011, 437). Agranoff \& McGuire $(2003,4)$ enforce this definition by emphasizing the implementation of inter-organisational arrangements to solve problems that could not be solved, or easily solved, by individuals. McGuire (2011, 442-443) defines the key elements for the achievement of effective network governance: consensual decision-making, trust, power distribution and common knowledge creation.

Collaboration is defined as the union of appreciations and / or tangible resources, such as information, money, work, etc., between two or more stakeholders, with the aim of solving a set of problems that could not be solved individually (Gray 1985, 912). Thus collaborative network governance may be conceived as a form of governance in which public and private actors work collectively in distinctive ways, using particular processes to establish laws and regulations for the provision of public goods (Ansell \& Gash 2008, 546).

Several studies reveal the importance of the participation of different stakeholders in decision making (Saarikoski et al. 2010) on the effects towards more sustainable development of the territory; it is also pointed out in the particular case of protected mountain areas (Erol et al. 2011; Hovardas \& Poirazidis 2007; Lane 2003).

In this study the degree of collaborative network governance is defined by the coincidence of objectives among stakeholders, the degree of consensus and trust in decision making and the intensity, duration and regularity of their relationships (Inglés 2013; Inglés \& Puig 2015).

\section{Sustainable development}

The conceptual core of sustainability, from which sustainable development arises, is that current decisions should not impair the expectations for maintaining or improving future living standards (Repetto 1985, 10).

The most broadly used definition of sustainable development is the one put forward in the Brundtland report (WCED 1987, 43), which conceives it as the development that meets the needs of the present without compromising the ability of future generations to meet their own needs. The concept of sustainable development has been traditionally divided into three parts - environmental, economic and social - and each part represents a pillar (WCED 1987). Further studies have expanded it by introducing a fourth element: the institutional dimension (Meadowcroft et al. 2005).

In this study sustainable development is conceived as a system composed of four dimensions: social, economic, environmental and political-institutional, and of the interactions within each of them and between one dimension and another (Sepúlveda 2008; Inglés 2013; Inglés \& Puig 2015). Achievement of genuine sustainable development therefore requires achieving a balance between its four dimensions.

\section{Method}

This article presents a case study design. It is based on the analysis of four conflicts developed in two protected mountain areas in Catalonia (Spain). A total of twenty face-to-face in-depth interviews were carried out with key stakeholders involved in the decision-making process developed to solve each of the conflicts in the past. The interviewees were selected using the snowball technique and following the steps defined by Heinemann (2003). Data collection took place between October 2011 and June 2012. Interviewees were introduced to the topic in a broad way to let them express themselves on the different dimensions that were analysed in relation to each case (see Table 1). An interview guide featuring the main dimensions and variables was presented to the interviewees. Afterwards they were asked to talk about all of them in the order they preferred. Appendix lists the dimensions and the variables that the interviewer had used to encourage the interviewee to talk about each of them. The interviews lasted one hour and twelve minutes on average.

The resulting texts of the interview transcriptions were analysed using QSR NVivo (QSR International Pty 1999-2008). Indicators indices were defined to allow the comparison between the four cases (see Table 1), and were based on the perceptions of the interviewees on each dimension, after quantification of the qualitative information.

Table 1 - Concepts, dimensions and indices of indicators
\begin{tabular}{|l|l|l|}
\hline Concepts & Dimensions & Indices \\
\hline $\begin{array}{l}\text { Mode of govern- } \\
\text { ance }\end{array}$ & $\begin{array}{l}\text { - Network of } \\
\text { relationships } \\
\text { Collaborative } \\
\text { processes }\end{array}$ & $\begin{array}{l}\text { Collaborative } \\
\text { network index }\end{array}$ \\
\hline $\begin{array}{l}\text { Consequences on } \\
\text { the sustainability of } \\
\text { the development }\end{array}$ & $\begin{array}{l}\text { - Ecological dimension } \\
\text { - Social dimension } \\
\text { Economic dimension }\end{array}$ & $\begin{array}{l}\text { Sustainability } \\
\text { index }\end{array}$ \\
\hline
\end{tabular}

The case studies. Two protected mountain areas: four conflicts

The analysis is focused on protected mountain areas classified under the Natural Park preservation category defined by Law 12/1985 of natural areas, enforced by the Government of Catalonia (Spain). This selection ensured a minimum management structure, where the mode of governance could be analysed, which could not be guaranteed in any non-protected mountain area. Furthermore, in each of the areas we selected two conflicts that had been generated by some kind of sports practice.

The following maps (Figure $1 \& 2$ ) show the boundaries and location of the two case studies in Catalonia (Spain): Montseny Natural Park (41 4 $47^{\prime} 36^{\prime \prime} \mathrm{N}$, $\left.2^{\circ} 24^{\prime} 11^{\prime \prime} \mathrm{E}\right)$ and Garraf Park (41 $16^{\prime} 26^{\prime \prime} \mathrm{N}$, $\left.1^{\circ} 54^{\prime} 51^{\prime \prime} \mathrm{E}\right)$. 


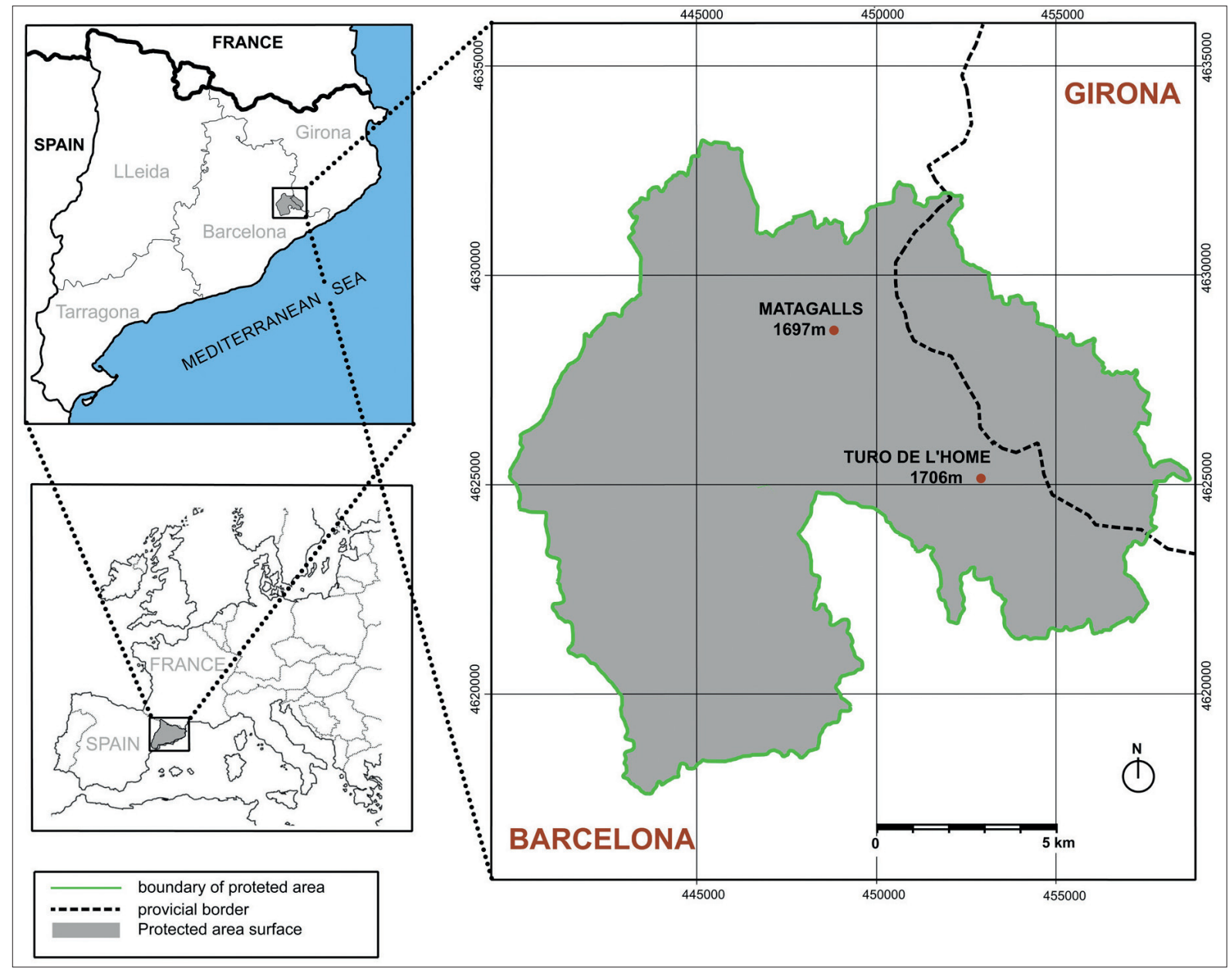

Figure 1 - Location and boundaries of Montseny Natural Park (Generalitat de Catalunya 2014).

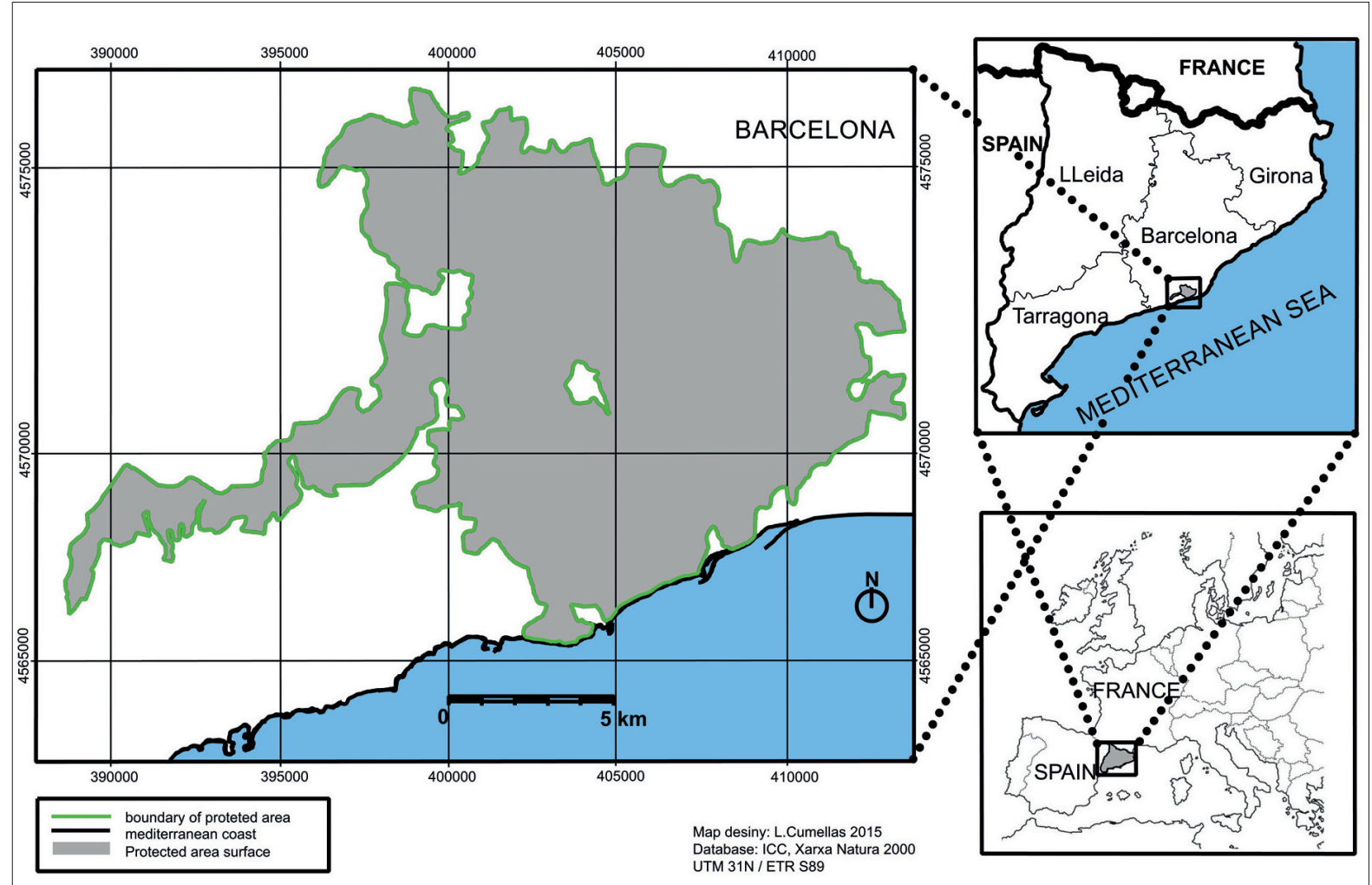

Figure 2 - Location and boundaries of Garraf Park (Generalitat de Catalunya, 2014). 
Acronyms were used to identify each of the conflict situations in the text and in figures and tables. MO corresponds to Montseny Natural Park and GA to Garraf Park. Each letter corresponds to a conflict (A: hang-gliding; B: ultra-trail race; C: climbing; D: hunting).

1. Montseny Natural Park (MO) covers a total area of 31064 hectares. It was designated as a natural park in 1987; it is one of the oldest natural parks in Catalonia and was included in the World Network of Biosphere Reserves by UNESCO in 1978.

- MO.A. Hang-gliding. A high degree of land erosion in the hill of Turó de l'Home (1708 m) was caused by the access of motorized vehicles, including the hang-gliders.

- MO.B. Ultra-trail race. The Matagalls-Montserrat Trail Race is a non-competitive endurance race on mountain trails that consists of getting from the top of Matagalls (1699 m), to Montserrat (709 m), a distance of $83.4 \mathrm{~km}$, in under 24 hours. A large increase in the number of participants generated i) severe erosion in the soil conditions of the area at the top of Matagalls; and ii) severe congestion in adjacent villages, impeding communication and traffic of the inhabitants.

The key stakeholders interviewed were the director of the natural park, the mayor of the municipality where the trail race starts, two representatives of the hang-gliders and one representative each of the Catalan Aerial Federation, of the hiking association that organizes the trail race, of the park informers, of the park officers and of an ecologist group $(n=10)$.

2. Garraf Park (GA) extends over an area of 12377 hectares. Its Special Plan was approved in 1986, it is included in the Catalan Natural Interest Areas Plan (PEIN), and its designation as a natural park is being processed.

- GA.C. Climbing. The increase in the number of climbers conflicted with the preservation of the habitat and nesting of raptors in the walls. The birds felt threatened and forced to leave the area.
- GA.D. Hunting. The increase in the number of hunters and the lack of restrictions, temporal and spatial limitations or regulation in the area led to a decrease in its biodiversity.

The key stakeholders selected in this case were the director of the natural park, the conseller (minister) of Agriculture and Livestock of the Catalan Government, two representatives of the climbers, and one representative each of the Catalan Hiking Federation, of the Catalan Hunting Federation, of the hunters, of the park biologists, of the park officers and of a hiking association $(\mathrm{n}=10)$.

\section{Indices of indicators}

Because of the complexity acquired by the two main research concepts after their operationalization, an index (see Table 1) was defined for each concept to group together the corresponding indicators. Their definition and calculation process are explained as follows (Inglés \& Puig 2015):

a) Collaborative network index. It assigns a quantitative value to the degree of interconnection and collaboration in the network of relations created between stakeholders. A set of numerical values was established for the possible degrees of each of the indicators used for its description. Table 2 defines the categories for each of the indicators, covering a range of 0 to 6 points each, depending on whether they are close to (6) or far from $(0)$ a theoretical collaborative network governance structure.

The collaborative network index thus consists of the sum of the results achieved in each of the indicators shown in Table 2, obtained from assessment of each of the interviewees. The following formulae summarize the process of arriving at the collaboration network index (CNindex).

$$
\bar{X}=\frac{\sum_{i=1}^{n} \overline{x_{l}}}{n} \quad \ldots \ldots \ldots \ldots \ldots \ldots . . . . . \text { CNindex }=\frac{\bar{X}}{30} \cdot 10
$$

To calculate the global average result $(\mathrm{X})$, the sum of the average results obtained on each of the items

Table 2 - Indicators of measuring the collaborative network structure degree. Numerical gradation: 0 far and 6 close to a theoretical collaborative network governance structure.

\begin{tabular}{|l|l|r|}
\hline Items of analysis & Indicators of the level of collaboration within the network & Numerical gradations \\
\hline Directly interconnected stakeholders & Stakeholders in direct relation during the process & $0-6$ \\
\hline \multirow{4}{*}{ Coincidence of objectives } & Totally opposed & $0-2$ \\
\cline { 2 - 3 } & Opposed but trying to align their positions & $2.1-4$ \\
\cline { 2 - 3 } & Totally coincidental objectives & $4.1-6$ \\
\hline \multirow{4}{*}{ Degree of consensus } & Power of decision of a central stakeholder & $0-2$ \\
\cline { 2 - 3 } & Imbalance in stakeholders' power but attempt at consensus & $2.1-4$ \\
\cline { 2 - 3 } & Total consensus in the decisions & $4.1-6$ \\
\hline \multirow{3}{*}{ Intensity/Trust } & Bad relationship/General social tension & $0-2$ \\
\cline { 2 - 3 } & Tension between some stakeholders and trust among others & $2.1-4$ \\
\cline { 2 - 3 } & Good relationship/General trust & $4.1-6$ \\
\hline \multirow{3}{*}{ Duration/Regularity } & Occasional collaboration & $0-2$ \\
\cline { 2 - 3 } & Contact maintenance/Intermittent meetings & $2.1-4$ \\
\cline { 2 - 3 } & Collaboration maintenance/Permanent relationship & $4.1-6$ \\
\hline
\end{tabular}


Table 3 - Scores for the quantification of the interviewee's perception on the impact of the solution on each dimension.

\begin{tabular}{|l|l|}
\hline Interviewee's perception & Score for quantification \\
\hline Positive effects & +10 \\
\hline \multirow{2}{*}{ No effects } & +5 \\
\cline { 2 - 2 } & $\begin{array}{l}-5 \text { (if the situation was previously } \\
\text { perceived as positive) }\end{array}$ \\
\hline Negative effects & $\begin{array}{l}-10 \text { (if the situation was previously } \\
\text { perceived as negative) }\end{array}$ \\
\hline
\end{tabular}

of analysis $\left(\sum_{i=1}^{n} \bar{x}_{l}\right)$ is divided by the (n) of items of analysis. The global average $(\mathrm{X})$ is then divided by the maximum possible value of the global average result (30) and then standardized to a basis of 10 points in order to make it comparable to the sustainability index.

b) Sustainability index. This assigns a quantitative value to the effects of the different identified strategies on the degree of sustainability of the development of the area. The effects of the diverse strategies were analysed by means of the interviewees' assessments, based on their own perceptions and on their previous formation and professional experience. The process consisted of allocating 10 points to a particular dimension when an interviewee felt that the overall solution had generated a positive effect on it, and of deducting 10 points when an interviewee saw the strategy as harmful to that dimension. If the interviewee reckoned that the strategy had not had any effect on that dimension, 5 points were scored to this dimension if they thought that the situation was positive before the implementation of the strategy, and 5 points were deducted when the situation was previously negative. Table 3 lists the scores attributed to the interviewees' perception on the impact of the solution on each dimension in order to quantify the initial qualitative data.

The sum of the scores given to the perceptions of each of the interviewees indicates the overall assessment of the impact of the solution on each of the dimensions. The addition of these four values results in the sustainability index, with a maximum value of 40 points in each case.

As in the collaborative network index, the following formulae summarize the process of arriving at the sustainability index (SUSindex).

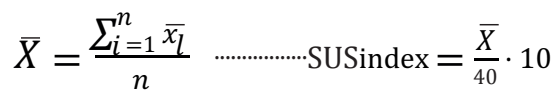

It consists of the same process of calculation, but in this case the global average result is of a value of 40 .

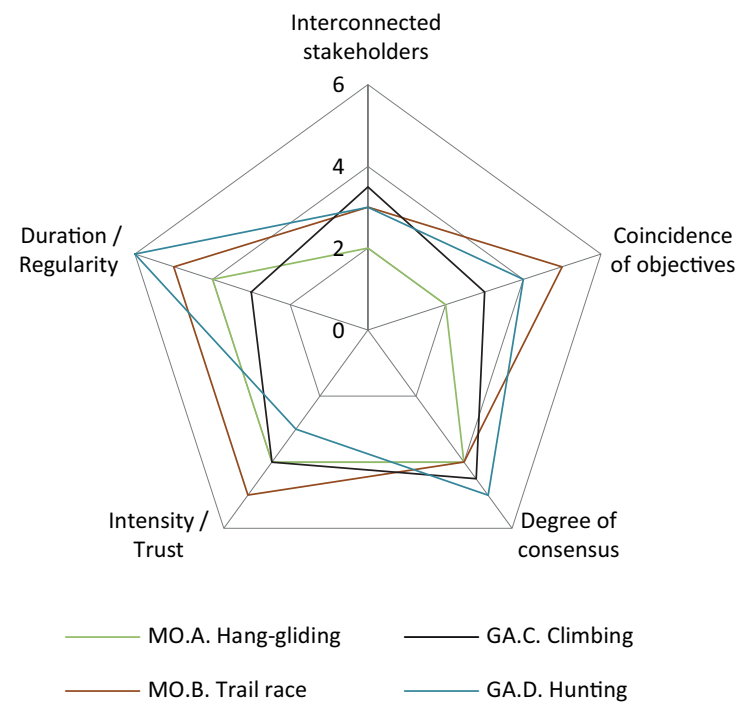

Figure 3 - Collaborative network indicators by conflict situations.

The result is also standardized to a basis of 10 points to allow the comparison between indices.

\section{Results}

The analysis of the cases is based on the data resulting from quantification of qualitative information, although each case has previously been analysed independently by the information gathered in the in-depth interview.

In this section the structure of governance in each case is shown using the indicators of a collaborative network and its final index. The consequences of the final solution to each conflict on the sustainability of the development of the area is also described using the values for each of the dimensions and of its resulting sustainability index in each case. Finally, the existing correlation between both indices is shown.

The mode of governance: collaborative network index

The values given to the above-mentioned indicators (see Table 2) are shown in a radial graph (Figure 3), where each vertex represents one of them. Table 4 shows the numerical values for each of the indicators and the resulting value of the collaborative network index in each conflict, standardized to a basis of 10 points. Figure 3 demonstrates that the greater the area covered by the different indicators in each

Table 4 - Collaborative network index and indicators by conflict situations: numerical values.

\begin{tabular}{|l|l|l|l|l|l|l|l|}
\cline { 2 - 8 } & $\begin{array}{l}\text { Interconnected } \\
\text { stakeholders } \\
\left(X_{1}\right)\end{array}$ & $\begin{array}{l}\text { Coincidence } \\
\text { of objectives } \\
\left(X_{2}\right)\end{array}$ & $\begin{array}{l}\text { Degree of } \\
\text { consensus } \\
\left(X_{3}\right)\end{array}$ & $\begin{array}{l}\text { Intensity / } \\
\text { Trust } \\
\left(X_{4}\right)\end{array}$ & $\begin{array}{l}\text { Duration/ } \\
\text { Regularity } \\
\left(X_{5}\right)\end{array}$ & $\begin{array}{l}\text { Index } \\
\text { (10 scale) })\end{array}$ & $\begin{array}{l}\text { Interviewees } \\
(\mathbf{n})\end{array}$ \\
\hline MO.A & 2 & 2 & 4 & 4 & 4 & 5.33 & 10 \\
\hline MO.B. & 3 & 5 & 4 & 5 & 5 & $\mathbf{7 . 3 3}$ & 10 \\
\hline GA.C. & 3.5 & 3 & 4,5 & 4 & 3 & $\mathbf{6 . 0 0}$ & 10 \\
\hline GA.D. & 3 & 4 & 5 & 3 & 6 & $\mathbf{7 . 0 0}$ & 10 \\
\hline
\end{tabular}




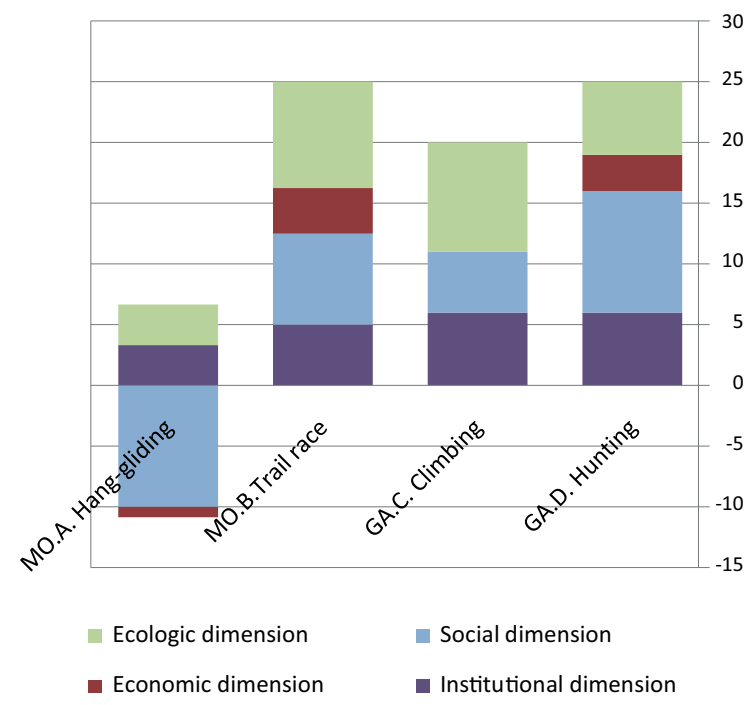

Figure 4-Sustainability index, by dimensions and conflict situations.

case, the greater the degree of collaborative network governance.

The area of all four cases consists of a polygon with sides of different length and different distances between their vertices, meaning that they have got diverse values in each of the indicators. In GA.D (hunting) the value of duration / frequency of the collaborative relationship stands out above the rest, since the connection is based on a permanent coalition for the joint management of the hunting area. Similar initial goals, cooperation and trust between stakeholders have facilitated the final consensus.

In the conflicts MO.B (trail race) and GA.D (hunting), the coincidence of objectives between the stakeholders involved is remarkable. In MO.B the relevant stakeholders ended up coming together in a decision in which all of them feel a part and have benefited. In this case the value of intensity and trust of the collaborative relationship also stands out, because the dialogues between park managers and the organizers of the trail-race have been on-going for over 10 years.

In the case of hang-gliding (MO.A), the existing close relationship between the representatives of the principal stakeholders in the decision making (park managers and Aerial Federation) allowed not only reducing the tension with some of the practitioners, but also reaching a consensual agreement to solve the conflict. In GA.C (climbing), despite the initial tension, the structure of relations established during the procedure was of great trust between the various stakeholders involved in the collaborative process. A committee was constituted of park representatives, the government and the Hiking Federation and culminated in the drafting of a consensual agreement.
Table 5 - Sustainability index, by dimensions and conflicts: numerical values.

\begin{tabular}{|l|r|r|r|r|}
\cline { 2 - 5 } \multicolumn{1}{c|}{} & MO.A & MO.B & GA.C & GA.D \\
\hline Ecologic dimension $\left(\mathbf{X}_{1}\right)$ & 3.33 & 8.75 & 9.00 & 6.00 \\
\hline Economic dimension $\left(\mathbf{X}_{1}\right)$ & -0.83 & 3.75 & 0.00 & 3.00 \\
\hline Social dimension $\left(\mathbf{X}_{1}\right)$ & -10.00 & 7.50 & 5.00 & 10.00 \\
\hline Institutional dimension $\left(\mathbf{X}_{1}\right)$ & 3.33 & 5.00 & 6.00 & 6.00 \\
\hline Sustainability index $(10$ scale) & -1.04 & $\mathbf{6 . 2 5}$ & $\mathbf{5 . 0 0}$ & $\mathbf{6 . 2 5}$ \\
\hline Interviewees $(\mathbf{n})$ & 10 & 10 & 10 & 10 \\
\hline
\end{tabular}

Index of sustainability: impact of the conflict solutions

In this section interviewees' perception of the consequences of the global strategy applied in each case is shown in Figure 4, where colours in each case differentiate the effects on the different dimensions of its development.

Table 5 shows the numerical values of the interviewees' assessments of the effects on each of the dimensions and the value of the resulting sustainability index in each case, standardized to a basis of 10 points.

Figure 4 reveals that the only solutions with positive effects on the four dimensions of development are the ones carried out for solving conflicts MO.B and GA.D; these two solutions can be categorized as sustainable.

In MO.B, changing the starting point of the race and so removing the initial descent from the summit of Matagalls from the track, reduced soil erosion considerably, at the same time improving the congestion situation in the surrounding area. In GA.D the establishment of a tripartite joint management of the hunting area allowed the restoration of the population of native species in the area as well as reducing the conflict generated by the confluence with hikers.

In conflict GA.C, the solution consisted in drafting an agreement to regulate the periods of the year and the specific areas where climbing is allowed and where it is not. It represented benefits for all dimensions of the development except the economic one. In MO.A (hang-gliding), based on the regulation of motorized access to the top of Matagalls, we can see how the values of effects on ecological and institutional dimensions are positive. The remarkable decline in the practice of hang-gliding in the area generates negative values for the economic and social dimensions.

Correlation between the collaborative network degree and the sustainability of the development

In this last section we present the relation between the mode of governance in which the final solution was framed and its effects on the degree of sustainability in the development of the area, in each case by the correlation of their resulting indices.

In Figure 5 we can observe that in three of the four cases a close relationship exists between the index of collaborative network and that of sustainability. In the case of MO.A, although there is a great difference 
between the values of both indices, we can see that both indices return the lowest values compared with the other cases. The data thus confirm that the greater the degree of networking and collaboration between stakeholders, the higher is the degree of sustainability of the development generated by the adopted solution strategy. Some examples can illustrate this assumption: the great collaboration reached between the Montseny Natural Park managers, the organizers of the race and the city council in the conflict over MO.B; or the coalition for the co-management of the hunting area or the regulation of the climbing zonification in Garraf Park (GA.C; GA.D). In these situations, the values of both the collaborative network index and that of sustainability are high. And in MO.A (hang-gliding), a lower value of its collaborative network index has also generated a less sustainable solution.

The Pearson product-moment correlation coefficient between these two indices confirms this statement with a value of $0.8767(\mathrm{P}=0.001)$.

\section{Discussion and conclusions}

This research has attempted to define the structures of governance developed in each of the conflicts analysed and how their characteristics influenced the sustainability of the development of the relevant area. The comparison between the different selected cases has evidenced, by the correlation between the index of collaborative network and that of sustainability, that a greater degree of network relation and the application of collaboration processes between stakeholders engender a greater degree of sustainability in the development of the area.

In this final section this result is discussed by comparing the conclusions drawn in related studies.

Several studies point out how collaboration between organizations generates benefits for achieving a greater degree of sustainability in the recreational management of protected natural areas. In his overview of the benefits of shared management, Martínez (2004) identified conflict management, established social relations and decentralization of central power as the principles of sustainable governance. Durán (2009) shows how a horizontal relationship between the park's environmental authorities, scientists and the local community in the governance of a natural area generates more sustainable solutions. This fact is also confirmed by Geneletti \& Van Duren (2008) in their proposal of zonification of a natural site, based on the participation of all the stakeholders involved in the decisionmaking processes. We thus see how the arguments put forward in these works connect with our results.

These results seem to indicate the existence of a collaborative network structure as a panacea for the achievement of sustainable development. We want to point out that a set of favourable conditions is needed to guarantee this correlation, as several studies have revealed. These conditions, stated as follows, can rep-

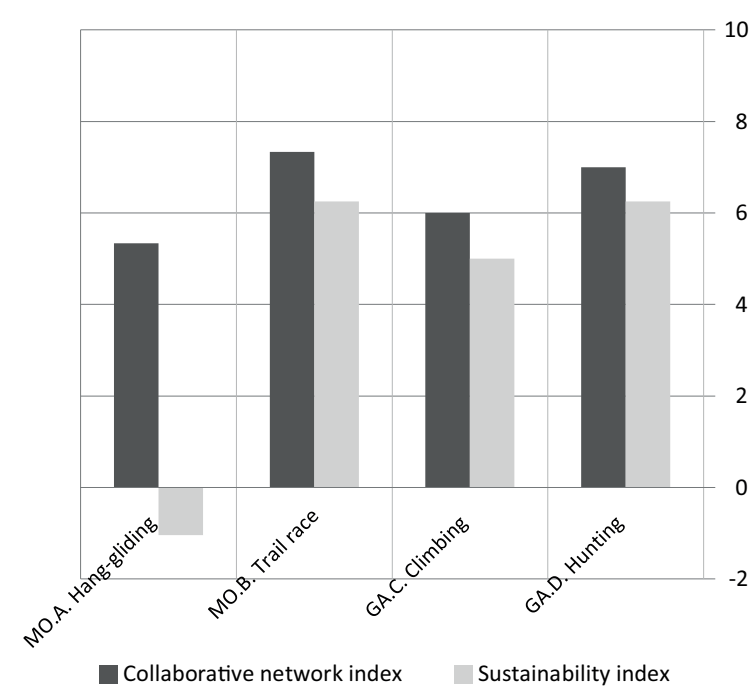

Figure 5 - Collaborative network index and sustainability index, by conflict situations.

resent a set of recommendations to achieve a more sustainable management of any mountain sport in a natural area.

The existence of scientific knowledge (Stensland 2012), its application to evaluate the efficiency of the measures adopted (Heylings \& Bravo 2007), educational and environmental awareness programmes (Martínez 2004; Schusler et al. 2003) and the establishment of a common perception of actions that may be regarded as having positive or negative impact on the development (Rech \& Mounet 2011) can be catalogued as the most crucial conditions to ensure the achievement of sustainable development in any existing collaborative network.

The generalization of the results of this study is restricted by some limitations. The fact that the conflicts took place in the past means that the data are conditioned by the interviewee's memories. Information on governance was based on the perceptions of the stakeholders involved and might have limited its reliability. Impact on sustainability was assessed by subjective information; thus a future challenge would be the definition and use of objective indicators.

These limitations represent a great opportunity for future studies, which, being based on a longitudinal study, would allow a real-time monitoring process of the conflicts and of their resolution processes and consequences on the development of the relevant areas.

In conclusion, this article points out the importance of a collaborative network governance structure when managing sports practice on protected mountain areas and their effect on the achievement of more sustainable development. Deeper research is needed to explore the sports management of natural sites further towards a more sustainable development. 


\section{Acknowledgments}

This study was supported by the Institut Nacional d'Educació Física de Catalunya (INEFC), of the Generalitat de Catalunya. Part of the research was developed at the Institut de Hautes Études en Administration Publique (IDHEAP - Lausanne, Switzerland), supported by the Agency for Management of University and Research Grants (AGAUR) in Catalunya.

The authors would like to specially thank professor Klaus Heinemann for his support and assistance.

\section{Appendix}

List of dimensions and variables to help the interviewer:

Conflict situation

- General description: origin/development/final solution

Context

- Legal, political, economic, sociocultural

Involved stakeholders

- Actions and strategies

- Interests / ideology / opinion

- Collaborative relations

- Power / legitimacy / urgency

Consequences of the solution

- Ecologic dimension/social dimension/ economic dimension / institutional dimension

\section{References}

Agranoff, R. \& M. McGuire 2003. Collaborative Public Management: New Strategies for Local Governments. Washington, D.C.

Ansell, C. \& A. Gash 2008. Collaborative Governance in Theory and practice. Journal of Public Administration Research and Theory 18: 543-571.

De Andrés, A., R. Blanco, J. Pertejo \& M.J. Prats 1995. Manual para la Mejora de la Calidad Ambiental de las Actividades Recreativas en la Naturaleza. Madrid. [In Spanish]

Dingle, G. 2009. Sustaining the race: a review of literature pertaining to the environmental sustainability of motorsport. International Journal of Sports Marketing \& Sponsorship 11(1): 80-96.

Durán, C.A. 2009. Gobernanza en los Parques Nacionales Naturales Colombianos. Reflexiones a partir del Caso de la Comunidad Orika y su Participación en la Conservación del Parque Nacional Natural Corales del Rosario y San Bernardo. Revista de Estudios Sociales 32: 60-73. [In Spanish]

Erol, S.Y., Y. Kuvan \& H.T. Yildirim 2011. The general characteristics and main problems of national parks in Turkey. African Journal of Agricultural Research 6(23): 5377-5385.

Fyall, A. \& L. Jago 2009. Sustainability in Sport \& Tourism. Journal of Sport Tourism 14(2/3): 77-81.

Geneletti, D. \& I. van Duren 2008. Protected area zoning for conservation and use: A combination of spatial multicriteria and multiobjective evaluation. Landscape and Urban Planning 85(2): 97-110.

Generalitat de Catalunya 2014. SIMA. Servei Interactiu de Mapes Ambientals. Available at: http://sima. gencat.cat/ (accessed 25/06/2015)

Gray, B. 1985. Conditions Facilitating Interorganizational Collaboration. Human Relations 38: 911-936.

Heinemann, K. 2003. Introducción a la metodología de la investigación empirica. En las Ciencias del Deporte. Barcelona: Paidotribo. [In Spanish]

Heylings, P. \& M. Bravo 2007. Evaluating governance: A process for understanding how co-management is functioning, and why, in the Galapagos Marine Reserve. Ocean \& Coastal Management 50(3/4): 174-208.

Hovardas, T. \& K. Poirazidis 2007. Environmental policy beliefs of stakeholders in protected area management. Environmental Management 39(4): 515-525.

Inglés, E. 2013. Estratègies de Gestió de la Pràctica Esportiva per al Desenvolupament Sostenible. Un Estudi de Casos sobre Governança i Stakeholders. Doctoral thesis. Universitat de Barcelona. Barcelona.

Inglés, E. \& N. Puig 2015. Sports management in coastal protected areas. A case study on collaborative network governance towards sustainable development. Ocean \& Coastal Management. Advanced online publication. doi: http://dx.doi.org/10.1016/j.ocecoaman.2015.07.018

Lagardera, F. \& J.R. Martínez 1998. "Deporte y Ecología: la Emergencia de un Conflicto”. In: M. García Ferrando, N. Puig \& F. Lagardera (eds.), Sociología del deporte: 179-204. Madrid. [In Spanish]

Lane, M.B. 2003. Decentralization or privatization of environmental governance? Forest conflict and bioregional assessment in Australia. Journal of Rural Studies 19(3): 283-294.

Mallen, C., J. Stevens, L. Adams \& S. McRoberts 2010. The Assessment of the Environmental Performance of an International Multi-Sport Event. European Sport Management Quarterly 10(1): 97-122.

Martínez, Z. 2004. "Cogestión de Recursos Naturales en la Región Atlántica de Colombia". Innovar 14(23): 158-167. [In Spanish]

Mayntz, R. 1998. New challenges to Governance Theory. Jean Monnet Chair Paper no. 50. Florence: Robert Schuman Centre of the European University.

McGuire, M. 2011. Network Management. In: M. Bevir (ed.), The SAGE Handbook of Governance: 436453. London.

Meadowcroft, J., N.K. Farrell \& J. Spangenberg 2005. Developing a Framework for Sustainability Governance in the European Union. International Journal for Sustainable Development 9: 3-11. 
Powell, W.W. 1990. Neither Market nor Hierarchy: Network Forms of Organization. Research in Organizational Behaviour 12: 295-336.

Rech, Y. \& J.P. Mounet 2011. Les sports de nature en debat: receptions differenciées de la gestion participative dans le Parc naturel regional de Chartreuse. Developpement Durable et Territoires 2(3): 1-18. [In French]

Repetto, R. 1985. The Global Possible-Resources, Development and the New Century. New Haven.

Rhodes, R.A.W. 1997. Understanding Governance. Policy Networks, Governance, Reflexivity and Accountability. Buckingham/Philadelphia.

Saarikoski, H., J. Tikkanen \& L.A. Leskinen 2010. Public participation in practice - Assessing public participation in the preparation of regional forest programs in Northern Finland. Forest Policy and Economics 12(5): 349-356.

Schusler, T.M., D.J. Decker \& M.J. Pfeffer 2003. Social Learning for Collaborative Natural Resource Management. Society \& Natural Resources 16(4): 309-326.

Sepúlveda, S. 2008. Gestión del Desarrollo Sostenible en Territorios Rurales: Métodos para la Planificación. San José, C.R.: IICA (Instituto Interamericano de Cooperación para la Agricultura). [In Spanish]

Sharma, A. \& K. Kearins 2011. Interorganizational Collaboration for Regional Sustainability: What Happens When Organizational Representatives Come Together? The Journal of Applied Behavioral Science 47(2): 168-203.

Stensland, S. 2012. Typology of landowners in Norwegian salmon angling: attitudes towards river owner organisations and management actions. Fisheries Management and Ecology 19(4): 273-282.

WCED (World Commission on Environment and Development) 1987. Our Common Future. Report of the United Nations WCED. Oxford.

\section{Authors}

\section{Eduard Inglés-Yuba}

Associate professor of Outdoor Activities at the National Institute of Physical Education (Barcelona). $\mathrm{PhD}$ in Sports Sciences (University of Barcelona). Master in Citizenship and Human Rights (University of Barcelona). Main research areas: sustainable sports management, sports organizations.

E-mail: eduard.ingles@gencat.cat

\section{Núria Puig ${ }^{1}$}

Full professor of Sociology of Sport at the National Institute of Physical Education (Barcelona). PhD in Sociologie de la Connaissance (Université de Paris) and $\mathrm{PhD}$ in Philosophy and Educational Sciences (University of Barcelona). Main research areas: sociology of sport, sports organizations.

E-mail: nuriapuiginefc@gmail.com

\section{Víctor Labrador ${ }^{1}$}

Associate professor of Outdoor Activities at the National Institute of Physical Education (Barcelona). Master in Physical Activity and Education. Main research areas: physical education, disability and outdoor sports. E-mail: vlabrador@gencat.cat

${ }^{1}$ INEFC (Institut Nacional d'Educació Física de Catalunya) - Barcelona, GISEAFE (Grup d'Investigació Social i Educativa de l'Activitat Física i l'Esport), Av. Estadi, 12-22, 08038 Barcelona, Spain 